\title{
Analisis Kenyamanan Termis Kota Banda Aceh Berdasarkan Temperature Humidity Index, Discomfort Index dan Humidex
}

\author{
Diana Cahaya Siregar ${ }^{1, *}$, Nasyithah Az-Zahra Lubis², Muhajir ${ }^{3}$ \\ ${ }^{1}$ Stasiun Meteorologi Raja Haji Fisabilillah Tanjungpinang \\ Tanjungpinang, Kepulauan Riau 29125, Indonesia \\ *siregardianacahaya@gmail.com \\ ${ }^{2}$ Stasiun Meteorologi Sultan Iskandar Muda, Bandara SIM Blang Bintang, Banda Aceh 23374, Indonesia \\ nasyitahjhd@gmail.com \\ ${ }^{2}$ Stasiun Klimatologi Indrapuri, Jl. Banda Aceh Medan Km. 27 Indrapuri, Aceh Besar 23363, Indonesia \\ muhajir.m@yahoo.com
}

Received 17 May 2019, Revised 28 March 2020, Accepted 30 March 2020

\begin{abstract}
The development of a city has had an impact on decreasing the quantity of vegetation cover and green area. The purpose of this study was to determine the thermic comfort level using the Temperature Humidity Index (THI), Discomfort Index (DI), and Humidex for the Banda Aceh City and its climatological trend during the period 1985-2012. The analysis of thermic comfort level using air temperature and humidity data for the period 1989-2018. Based on THI, the index value ranged from 23.2 to $25.8^{\circ} \mathrm{C}$. Based on DI, the index value ranged from 23.5 to $26.3{ }^{\circ} \mathrm{C}$. Based on Humidex, the index value ranged from 28.1 to $33.5^{\circ} \mathrm{C}$. Trend of the increasing of index value indicated that condition have been increasingly uncomfortable. Trend of the increasing of index value has been as a result of the changing on land-use becoming a built-up land (reducing the green open space), the rate of development, and urbanization. The analysis of thermic comfort level in Banda Aceh can be used as a consideration for adding the green open space and developing the city area based on the comfort of the resident population.
\end{abstract}

Keywords: Thermic Comfort, Heat Index, Urbanization

\begin{abstract}
Abstrak - Pembangunan kota berdampak terhadap penurunan kuantitas tutupan vegetasi dan kawasan hijau. Tujuan penelitian ini adalah mengetahui tingkat kenyamanan termis dengan menggunakan indeks panas Temperature Humidity Index (THI), Discomfort Index (DI), dan Humidex untuk wilayah Kota Banda Aceh dan kecenderungannya secara klimatologis selama periode 1985-2012. Analisis tingkat kenyamanan termis menggunakan data suhu dan kelembaban udara periode 1989-2018. Berdasarkan THI, nilai indeks berkisar 23,2-25,8 ${ }^{\circ} \mathrm{C}$. Berdasarkan DI, nilai indeks berkisar 23,5-26,3 ${ }^{\circ} \mathrm{C}$. Berdasarkan Humidex, nilai indeks berkisar 28,1-33,5 ${ }^{\circ} \mathrm{C}$. Kecenderungan peningkatan nilai indeks menunjukkan kondisi semakin tidak nyaman. Tren peningkatan nilai indeks sebagai dampak dari perubahan penggunaan lahan menjadi lahan terbangun (berkurangnya Ruang Terbuka Hijau), laju perkembangan dan urbanisasi di wilayah perkotaan. Analisis tingkat kenyamanan termis di Kota Banda Aceh diharapkan dapat digunakan sebagai pertimbangan penambahan Ruang Terbuka Hijau dan perancangan kota yang disesuaikan dengan kenyamanan populasi yang bermukim.

Kata Kunci: Kenyamanan Termis, Indeks Panas, Urbanisasi
\end{abstract}

\section{PENDAHULUAN}

Pembangunan kota berdampak terhadap penurunan kuantitas tutupan vegetasi dan kawasan hijau yang berfungsi sebagai peneduh, pengatur iklim mikro, dan penyerap polutan (Annisa $d k k$., 2015). Dampak yang paling dirasakan terhadap parameter iklim lainnya adalah perubahan suhu udara di lingkungan sekitar. Selain suhu udara, parameter iklim yang juga berpengaruh terhadap kenyamanan manusia adalah angin. Udara panas yang tercampur dengan udara dingin dapat terbawa ke tempat lain juga diakibatkan oleh hembusan angin. Perubahan suhu udara dan angin yang ekstrem merupakan hal yang langsung dapat dirasakan dan berpengaruh terhadap tingkat kenyamanan manusia (Wati \& Fatkhuroyan, 2017). Kondisi kenyamanan bagi setiap individu sangat bervariasi dan bersifat subjektif. Perasaan nyaman yang dirasakan oleh seseorang ditentukan oleh kenyamanan psikologis, fisiologis, dan sosiologis. Kenyamanan psikologis adalah perasaan nyaman dengan penekanan secara subyektif, personal, dan pribadi. Kenyamanan fisiologis berkaitan dengan lingkungan alam sekitar, misalnya kondisi thermal. Kenyamanan sosiologis berkaitan dengan suasana hubungan dengan anggota keluarga, teman, dan masyarakat.

Suhu udara biasanya digunakan sebagai indikator kenyamanan termis yang kita rasakan 
ketika sedang beraktivitas fisik atau berolah raga. Akan tetapi, suhu hanya merupakan salah satu faktor. Faktor iklim lainnya yang berpengaruh adalah kelembaban udara yang dapat digunakan untuk melakukan penilaian mengenai kenyamanan yang dirasakan manusia. Kenyamanan termis terbatas pada kondisi udara tidak ekstrem (moderate thermal environment) dimana manusia masih dapat mengantisipasi dirinya terhadap perubahan suhu udara di sekitarnya (Chindapol et al., 2016). Dalam kondisi suhu suatu daerah yang tidak ekstrem (sangat panas atau sangat dingin) dimana manusia tidak memerlukan usaha apapun seperti halnya menggigil atau mengeluarkan keringat dalam rangka mempertahankan suhu tubuhnya agar tetap berkisar pada $37^{\circ} \mathrm{C}$ (Karyono, 2001). Daerah suhu inilah yang kemudian disebut dengan suhu netral atau nyaman.

Hubungan kompleks antara faktor cuaca dengan kesehatan dan kenyamanan manusia diidentifikasikan dengan indeks biometeorologi. Indeks panas yang berkaitan dengan manusia dan lingkungan, antara lain: Heat Discomfort Index, Humidex, The Weather Stress Index, dan The Universal Thermal Climate Index (Spridonov et al., 2013). Temperature Humidity Index (THI) mengkombinasikan suhu dan kelembaban udara menjadi suatu nilai indeks dari kondisi panas yang dirasakan oleh manusia. Discomfort Index (DI) menghitung nilai suhu udara dan hidrometri parameter suhu titik embun sebagai kriteria tindakan perlindungan darurat saat nilainya melebihi batas tertentu untuk mengetahui tingkat kenyamanan termis yang dirasakan oleh suatu populasi. Humidex juga mengkombinasikan suhu dan kelembaban udara menjadi suatu nilai indeks yang merefleksikan suhu yang dirasakan oleh manusia.

Provinsi Aceh telah mengalami perkembangan pembangunan kota dan peningkatan jumlah penduduk. Pesatnya kegiatan pembangunan sarana dan prasarana di Kota Banda Aceh memicu pertambahan polutan di udara. Perkembangan pembangunan Kota Banda Aceh tentunya sangat mempengaruhi suhu udara akibat seperti terjadinya peningkatan suhu di pusat kota (Bahri $d k k$., 2012). Tujuan dari penelitian ini adalah mengetahui tingkat kenyamanan termis dengan menggunakan indeks panas THI, DI, dan Humidex untuk wilayah Kota Banda Aceh dan kecenderungannya secara klimatologis selama periode 1985-2012.

\section{METODE PENELITIAN}

\section{Lokasi Studi}

Penelitian ini dilakukan di wilayah Kota Banda Aceh dengan menggunakan parameter iklim mikro berupa suhu dan kelembaban udara. Data tersebut merupakan hasil observasi dari Stasiun Meteorologi Sultan Iskandar Muda selama 30 tahun (1989-2018). Penelitian ini akan membandingkan beberapa metode perhitungan indeks panas, yaitu THI, DI, dan Humidex. Selanjutnya nilai indeks panas yang diperoleh akan dikonversikan sesuai tabel interpretasi masing-masing metode untuk mengetahui kondisi kenyaman termis yang dirasakan selama 30 tahun belakangan.

\section{Analisis Data}

Temperature Humidity Index (THI) merupakan suatu metode yang menghasilkan nilai indeks dari kondisi panas yang dirasakan oleh manusia dengan cara mengkombinasikan suhu dan kelembaban udara (Effendy $d k k$., 2007). THI pertama kali ditemukan oleh Thom (1959) dan dimodifikasi oleh Nieuwolt (1977). Penentuan nilai THI menggunakan persamaan sebagai berikut:

$$
T H I=0.8 T+\left(\frac{R H . T}{500}\right)
$$

dimana THI adalah Temperature Humidity Index sebagai indeks panas $\left({ }^{\circ} \mathrm{C}\right), T$ adalah suhu udara $\left({ }^{\circ} \mathrm{C}\right)$, dan $R H$ adalah Relative Humidity atau kelembaban udara $(\%)$.

Tabel 1. Interpretasi indeks panas THI (Effendy $d k k$., 2007)

\begin{tabular}{|c|c|}
\hline Indeks THI & Kategori \\
\hline$\leq 21{ }^{\circ} \mathrm{C}$ & Nyaman \\
\hline $21-24^{\circ} \mathrm{C}$ & $\begin{array}{l}\text { Kondisi nyaman dirasakan oleh semua } \\
\text { populasi }\end{array}$ \\
\hline $24-27^{\circ} \mathrm{C}$ & $\begin{array}{l}\text { Ketidaknyamanan dirasakan oleh } 50 \% \\
\text { populasi }\end{array}$ \\
\hline$\geq 27^{\circ} \mathrm{C}$ & $\begin{array}{l}\text { Ketidaknyamanan dirasakan oleh } \\
\text { mayoritas populasi }\end{array}$ \\
\hline
\end{tabular}

Discomfort Index (DI) digunakan di beberapa negara untuk mengevaluasi ketidaknyamanan yang diekspresikan oleh penduduk dalam skala yang lebih besar (Georgi \& Zafriadis, 2006). DI pertama sekali diusulkan oleh Thom (1959). Indeks ini diperoleh dengan cara menghitung nilai suhu udara dan hidrometri parameter suhu titik embun atau nilai kelembaban udara relatif. Indeks ini digunakan di banyak negara sebagai kriteria tindakan perlindungan darurat saat nilainya melebihi batas tertentu. Penentuan nilai DI menggunakan persamaan sebagai berikut:

$$
D I=T-\{0.55 .(1-0.01 R H)(T-14.5)\}
$$

dimana DI adalah Discomfort Index sebagai indeks panas $\left({ }^{\circ} \mathrm{C}\right), T$ adalah suhu udara $\left({ }^{\circ} \mathrm{C}\right)$, dan $R H$ adalah Relative Humidity atau kelembaban udara (\%).

Schoen (2005), Humidex merupakan nilai indeks panas yang dirasakan oleh manusia dengan suhu dan kelembaban udara yang diukur secara aktual pada udara yang relatif kering (tekanan uap kurang dari $10 \mathrm{hPa}$ ). Humidex dikemukan oleh Masterson dan Richardson (1979) dalam penelitiannya dengan cara menghubungkan ketidaknyamanan termis di Kanada dengan menghitung nilai suhu udara dan kelembaban udara. 
Tabel 2. Interpretasi indeks panas DI (Georgi dan Zafriadis, 2006)

\begin{tabular}{cl}
\hline Indeks DI & \multicolumn{1}{c}{ Kategori } \\
\hline$\leq 21{ }^{\circ} \mathrm{C}$ & Nyaman \\
$21-24{ }^{\circ} \mathrm{C}$ & Ketidaknyamanan dirasakan oleh $<$ \\
& $50 \%$ populasi \\
$24-27{ }^{\circ} \mathrm{C}$ & $\begin{array}{l}\text { Ketidaknyamanan dirasakan oleh }> \\
50 \% \text { populasi }\end{array}$ \\
$27-29{ }^{\circ} \mathrm{C}$ & $\begin{array}{l}\text { Ketidaknyamanan dirasakan oleh } \\
\text { mayoritas populasi }\end{array}$ \\
$29-32{ }^{\circ} \mathrm{C}$ & $\begin{array}{l}\text { Ketidaknyamanan dirasakan oleh } \\
\text { semua populasi }\end{array}$ \\
$\geq 32{ }^{\circ} \mathrm{C}$ & Tahapan alarm medis \\
\hline
\end{tabular}

Penentuan nilai Humidex menggunakan persamaan sebagai berikut:

$$
\begin{aligned}
& \text { Humidex }=T+\frac{5}{9}(e-10) \\
& e=6.112\left(10^{\frac{7.5 T}{237.7+T}}\right)\left(\frac{R H}{100}\right)
\end{aligned}
$$

dimana Humidex adalah indeks panas $\left({ }^{\circ} \mathrm{C}\right), T$ adalah suhu udara $\left({ }^{\circ} \mathrm{C}\right)$, dan $R H$ adalah Relative Humidity atau kelembaban udara (\%).

Tabel 1. Interpretasi indeks panas Humidex (Spridonov

\begin{tabular}{|c|c|}
\hline $\begin{array}{c}\text { Indeks } \\
\text { Humidex } \\
\end{array}$ & Kategori \\
\hline$\leq 29^{\circ} \mathrm{C}$ & Nyaman \\
\hline $30-34{ }^{\circ} \mathrm{C}$ & Perasaan sedikit tidak nyaman \\
\hline $35-39^{\circ} \mathrm{C}$ & Perasaaan tidak nyaman \\
\hline $40-45^{\circ} \mathrm{C}$ & $\begin{array}{l}\text { Perasaan sangat tidak nyaman akibat } \\
\text { panas hingga menimbulkan rasa } \\
\text { tersengat akibat panas }\end{array}$ \\
\hline $46-53{ }^{\circ} \mathrm{C}$ & $\begin{array}{l}\text { Perasaan sangat tidak nyaman dan } \\
\text { hampir dapat menyebabkan penyakit } \\
\text { akibat serangan panas }\end{array}$ \\
\hline$\geq 54{ }^{\circ} \mathrm{C}$ & Kematian akibat panas \\
\hline
\end{tabular}
et al., 2013)

\section{HASIL PENELITIAN DAN ANALISIS}

Aceh memiliki keberagaman topografi pada tiap kabupaten. Keberagaman topografi dan letak geografis menyebabkan faktor iklim mikro seperti curah hujan, suhu udara, dan kelembaban udara di Aceh cukup signifikan dipengaruhi oleh keadaan lokal (Lubis $d k k$., 2018). Pertumbuhan populasi yang tinggal di Kota Banda Aceh menyebabkan perubahan kualitas lingkungan daerah perkotaan seperti adanya peningkatan suhu udara dari waktu ke waktu. Hal tersebut berdampak terhadap tingkat kenyamanan termis yang dirasakan oleh populasi juga mengalami perubahan.

Analisis tingkat kenyamanan termis berdasarkan THI, DI, dan Humidex di Kota Banda Aceh menggunakan data suhu dan kelembaban udara periode 1989-2018 menunjukkan adanya perubahan nilai indeks untuk tiap bulannya. Gambar 1 menunjukkan nilai indeks tingkat kenyamanan termis rata-rata bulanan di Kota Banda Aceh pada dasarnya cukup beragam. Berdasarkan THI, nilai indeks berkisar $23,2-25,8^{\circ} \mathrm{C}$. Berdasarkan $D I$, nilai indeks berkisar $23,5-26,3^{\circ} \mathrm{C}$. Berdasarkan Humidex, nilai indeks berkisar $28,1-33,5^{\circ} \mathrm{C}$. Interpretasi nilai indeks antara $T H I$ dan $D I$ tidak begitu jauh perbedaannya sehingga nilai indeks yang ditunjukkan hampir sama (berkisar $21-27^{\circ} \mathrm{C}$ ), dimana hal tersebut berbeda dengan Humidex (berkisar 29-54 ${ }^{\circ} \mathrm{C}$ ).

Pada dasarnya, peningkatan suhu udara (lebih hangat) berdampak terhadap penurunan kelembaban udara (massa udara kurang lembab) atau sebaliknya. Populasi akan merasa nyaman ketika suhu udara kondusif (dingin) seperti ketika terjadi hujan atau sebaliknya. Pada dasarnya, pengaruh radiasi sinar matahari memiliki peranan paling besar dalam meningkatkan paparan panas. Faktor yang paling mempengaruhi indeks tekanan paparan panas yaitu suhu global, kecepatan angin dan suhu udara (Huda \& Pandiangan, 2012). Berdasarkan Gambar 1, nilai indeks minimum tingkat kenyamanan termis di Kota Banda Aceh terjadi pada bulan Januari dan Desember. Hal tersebut sebagai dampak dari cukup giatnya konvektifitas antara atmosfer dan lautan yang berpeluang menghasilkan curah hujan yang cukup banyak. Nilai indeks maksimum tingkat kenyaman termis terjadi pada bulan Mei dimana terdapat transisi (musim peralihan) menuju musim kemarau di bulan Juni-Juli-Agustus (JJA). Hal tersebut sebagai dampak dari cukup signifikan pemanasan suhu udara yang terjadi (curah hujan yang terjadi sedikit).

\section{Indeks Kenyaman Termis Rata-rata Bulanan Periode 1989-2018 di Kota Banda Aceh}

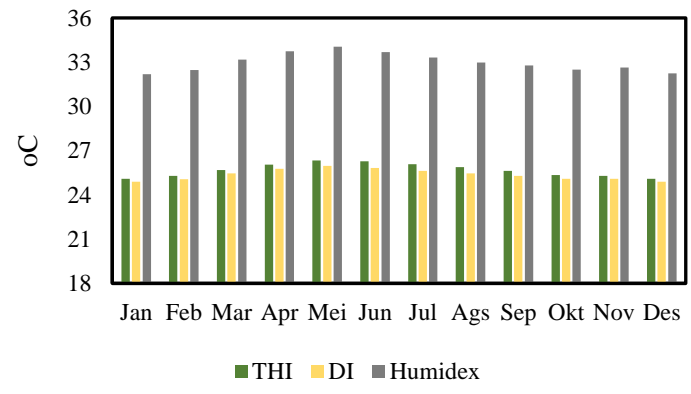

Gambar 1. Pola indeks kenyamanan termis rata-rata bulanan di Kota Banda Aceh

Analisis tingkat kenyaman termis di Kota Banda Aceh mengunakan data suhu dan kelembaban udara selama periode 1989-2018 ditunjukkan pada Gambar 2. Analisis dilakukan berdasarkan THI, DI, dan Humidex. Berdasarkan THI, tingkat kenyamanan termis yang dirasakan populasi yang tinggal di Kota Banda Aceh diinterpretasikan menjadi 3 kategori. Tingkat kenyamanan termis harian untuk: kondisi nyaman (dirasakan oleh semua populasi) sebesar $3,7 \%$ atau 13 hari/tahun, kondisi tidak nyaman (dirasakan oleh $50 \%$ populasi) sebesar $89,1 \%$ atau 325 hari/tahun, kondisi tidak nyaman (dirasakan oleh 
mayoritas populasi) sebesar $7,19 \%$ atau 26 hari/tahun.

Berdasarkan $D I$, tingkat kenyamanan termis yang dirasakan populasi yang tinggal di Kota Banda Aceh diinterpretasikan menjadi 3 kategori. Tingkat kenyamanan termis harian untuk: kondisi nyaman (dirasakan oleh sebagian kecil populasi) sebesar 5,14\% atau 19 hari/tahun, kondisi tidak nyaman (dirasakan oleh $50 \%$ populasi) sebesar $93,13 \%$ atau 340 hari/tahun, kondisi tidak nyaman (dirasakan oleh mayoritas populasi) sebesar $1,69 \%$ atau 6 hari/tahun. Berdasarkan Humidex, tingkat kenyamanan termis yang dirasakan populasi yang tinggal di Kota Banda Aceh diinterpretasikan menjadi 3 kategori. Tingkat kenyamanan termis harian untuk: kondisi nyaman sebesar $0,64 \%$ sebesar 2 hari/tahun, kondisi sedikit tidak nyaman sebesar $78,45 \%$ atau 286 hari/tahun, kondisi tidak nyaman sebesar $20,84 \%$ atau 76 hari/tahun.

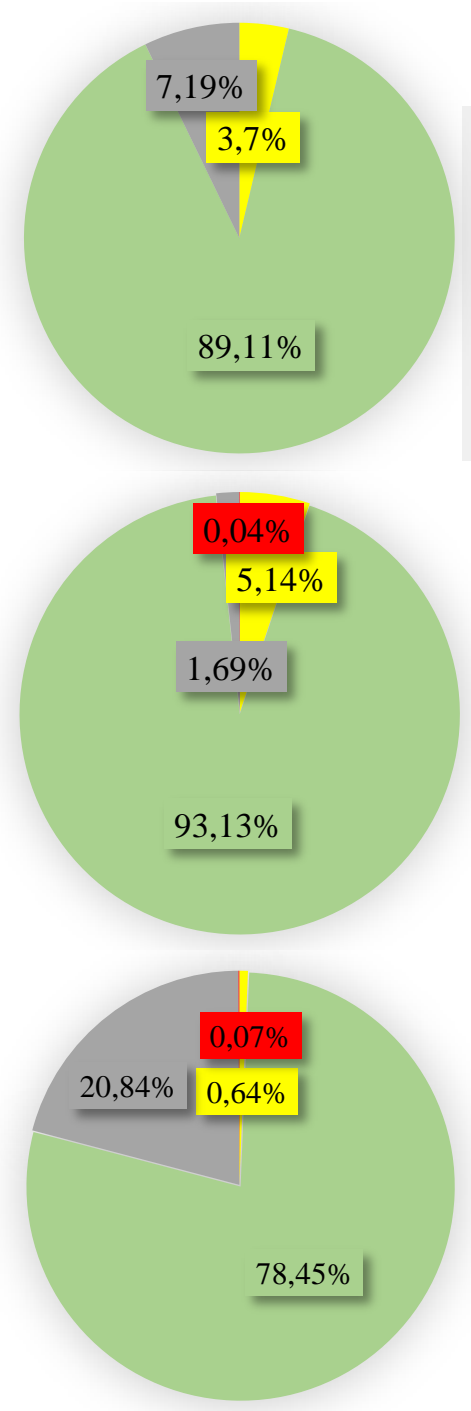

Berdasarkan Gambar 2, nilai indeks menunjukkan selama 30 tahun, populasi yang tinggal di Kota Banda Aceh merasakan kenyamanan termis pada kategori kondisi tidak nyaman (dirasakan oleh sebagian besar populasi). Kondisi tersebut dipengaruhi oleh adanya peningkatan suhu udara. Ketidaknyamanan tersebut biasanya dirasakan populasi khususnya pada siang hari. Fluktuasi suhu udara berkaitan erat dengan proses pertukaran energi yang berlangsung di atmosfer (Lakitan, 2002). Pada siang hari, sebagian dari radiasi matahari akan diserap oleh Gas Rumah Kaca (GRK) yang melayang di atmosfer. Serapan energi matahari akan menyebabkan suhu udara memanas. Suhu udara harian maksimum terjadi saat intensitas maksimum juga terjadi. Tutupan awan (albedo) yang cukup banyak berdampak terhadap suhu udara yang akan mendingin. Suhu permukaan memiliki nilai tertinggi pada penutupan lahan terbangun dan suhu permukaan terendah yang dimiliki oleh awan.

\section{Nilai indeks}

\section{Temperature Humidity Index (THI)}

Kondisi nyaman dirasakan oleh semua populasi

Ketidaknyamanan dirasakan oleh $50 \%$ populasi

Ketidaknyamanan dirasakan oleh mayoritas populasi

\section{Nilai indeks Discomfort Index (DI)}

Ketidaknyamanan dirasakan oleh $<50 \%$ populasi

Ketidaknyamanan dirasakan oleh $>50 \%$ populasi

Ketidaknyamanan dirasakan oleh mayoritas populasi

- Ketidaknyamanan dirasakan oleh semua populasi

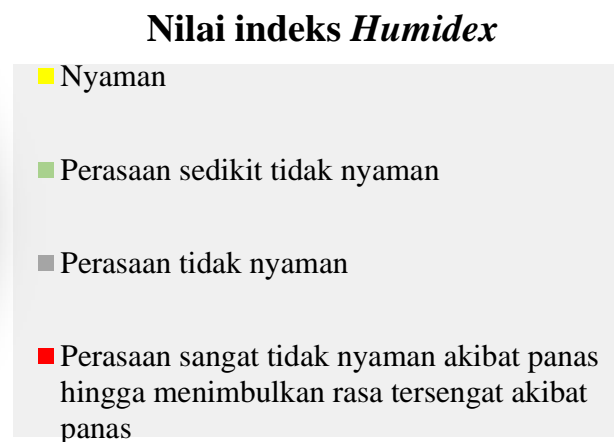

ngat akibat panas

Gambar 2. Diagram tingkat kenyamanan termis di Kota Banda Aceh

Gambar 3 menunjukkan tren tingkat kenyamanan termis yang dirasakan populasi di Kota Banda Aceh untuk periode 1989-2018. Tren tingkat kenyamanan termis mengalami kenaikan yang cukup tinggi pada kisaran tahun 1997 dan 1998. Hal tersebut sebagai dampak dari terjadinya El-Nino. Pada saat El-Nino 
terjadi, aliran massa uap air dari Indonesia mengalir ke Samudera Pasifik, sehingga berdampak terhadap defisit pasokan uap air di wilayah Indonesia. Jika uap air berkurang, cuaca yang terjadi cenderung dingin dan kering. Berdasarkan Gambar 3, peningkatan nilai indeks selama 30 tahun berkisar $0,03-0,8^{\circ} \mathrm{C}$. Kecenderungan peningkatan nilai indeks berdasarkan
THI berkisar $0,03-0,75^{\circ} \mathrm{C}$ dengan nilai koefisien determinasi sebesar 0,69 . Kecenderungan peningkatan nilai indeks berdasarkan DI berkisar $0,03-0,84^{\circ} \mathrm{C}$ dengan nilai koefisien determinasi sebesar 0,66. Kecenderungan peningkatan nilai indeks berdasarkan Humidex berkisar $0,05-0,82^{\circ} \mathrm{C}$ dengan nilai koefisien determinasi sebesar 0,64.

Tren Tingkat Kenyaman Termis Periode 1989-2018

Berdasarkan Temperature Humidity Index (THI), Discomfort Index (DI), dan Humidex

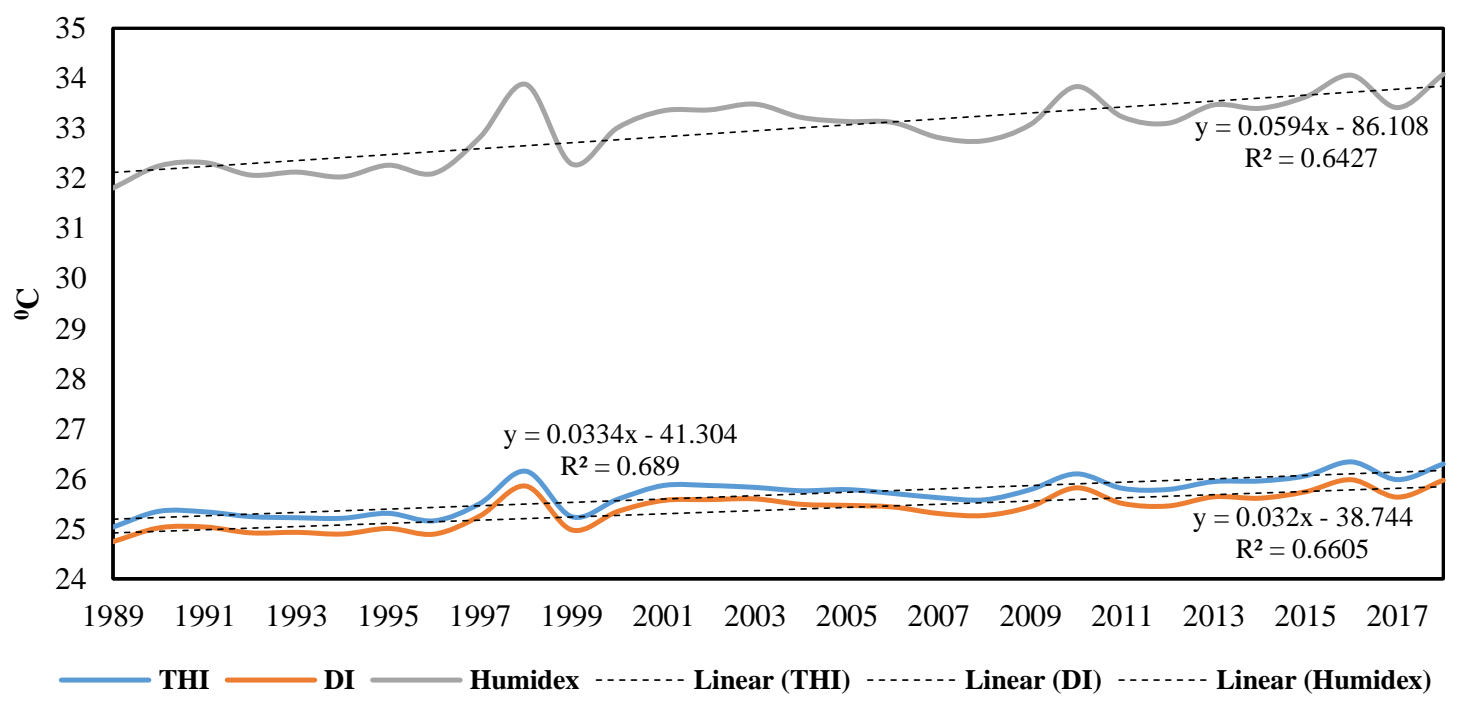

Gambar 3. Tren tingkat kenyamanan termis di Kota Banda Aceh

Terjadinya kecenderungan peningkatan nilai indeks tingkat kenyaman termis di Kota Banda Aceh selama 30 tahun disebabkan semakin tingginya laju perkembangan dan urbanisasi di wilayah perkotaan. Peningkatan suhu perkotaan juga disebabkan oleh padatnya bangunan dan gedung yang tinggi, sehingga memantulkan cahaya matahari ke segala arah pada siang hari dan melepaskan kalor pada malam hari. Salah satu upaya untuk penanggulangan pemanasan suhu perkotaan yaitu adanya penggalakan penanaman pohon atau hutan kota yang berperan dalam ameliorasi iklim mikro kawasan perkotaan (Rosianty $d k k ., 2018$ ).

Perlunya vegetasi atau Ruang Terbuka Hijau (RTH) untuk mengurangi GRK yang ada di atmosfer. Hal tersebut berdampak pada tingkat kenyamanan yang dirasakan populasi berkurang menjadi tidak nyaman menjadi nyaman (kondusif). Pada dasarnya, RTH dapat menurunkan suhu udara dan meningkatkan kelembaban udara. Berdasarkan penelitian yang dilakukan Bahri $d k k$. (2012) standar kebutuhan kondisi RTH yang ada di Kota Banda Aceh belum memenuhi standar luas dan distribusi kebutuhan RTH baik ditinjau berdasarkan luas wilayah maupun pendekatan kebutuhan oksigen. Kondisi yang ada jika berlanjut akan menyebabkan tingkat kenyamanan termis yang dirasakan populasi yang tinggal di Kota Banda Aceh berkurang menjadi tidak nyaman.

\section{KESIMPULAN}

Tingkat kenyamanan termis yang dirasakan populasi yang tinggal di Kota Banda Aceh berdasarkan indeks Temperature Humidity Index, Discomfort Index, dan Humidex menunjukkan adanya perubahan tingkat kenyamanan selama 30 tahun (periode 1989-2018). Kecenderungan peningkatan nilai indeks cenderung menunjukkan kondisi semakin tidak nyaman. Tren peningkatan nilai indeks sebagai dampak dari perubahan penggunaan lahan menjadi lahan terbangun, laju perkembangan, dan urbanisasi di wilayah perkotaan. Analisis tingkat kenyamanan termis di Kota Banda Aceh yang dikaji dalam penelitian ini dapat digunakan sebagai pertimbangan penambahan Ruang Terbuka Hijau dan perancangan Kota Banda Aceh yang disesuaikan dengan kenyamanan populasi yang bermukim.

\section{PENGAKUAN}

Terimakasih kepada kepala kantor dan para pegawai yang bekerja di Stasiun Meteorologi Sultan Iskandar Muda yang telah memberikan bantuan berupa penyediaan data yang digunakan dalam penelitian ini sehingga penelitian ini dapat diselesaikan dengan baik.

\section{DAFTAR PUSTAKA}


Annisa, N., Kurnain, A., Indrayatie, E. R., \& Peran, S. B. (2015). Iklim Mikro dan Indeks Ketidaknyamanan Taman Kota di Kelurahan Komet Kota Banjarbaru. Jurnal Enviro Scienteae. 11, 143-151. doi: 10.20527/es.v11i3.1104

Bahri, S., Darusman, \& Ali, S. A. (2012). Kebutuhan Ruang Terbuka Hijau Kota Banda Aceh. Jurnal Manajemen Sumberdaya Lahan, (1), 10-22.

Chindapol, S., Blair, J., Osmond, P., \& Prasad, D. (2016). A Suitable Thermal Stress Index for the Elderly in Summer Tropical Climates. 2016 iHBE Procedia Engineering, International High-Performance Built Environment Conference 2016 Series (SBE16), pp. 932-943.doi: 10.1016/j.proeng.2017.04.253

Effendy, S., Bey, A., Zain, A. F. M., \& Santosa, I. (2006). Peranan Ruang Terbuka Hijau Dalam Mengendalikan Suhu Udara dan Urban Heat Island Wilayah Jabotabek. Jurnal Agromet Indonesia, 20(1), 23-33. doi: 10.29244/j.agromet.20.1.23-33

Georgi, N. J. \& Zafiriadis, K. (2006). The Impact of Park Trees on Microclimate in Urban Areas. Urban Ecosyst, 9, 195-209.

Huda, L. N. \& Pandiangan, K. C. (2012). Kajian Termal Akibat Paparan Panas dan Perbaikan Lingkungan Kerja. Jurnal Teknik Industri, 14(2), 129-136. doi: 10.9744/jti.14.2.129-136

Karyono, T. H. (2001). Penelitian Kenyamanan Termis di Jakarta sebagai Acuan Suhu Nyaman Manusia di Indonesia. Jurnal Diseminasi Teknik Arsitektur, 29(1), 24-33.
Lakitan, B. (2002). Dasar-dasar Klimatologi, Bandung: Penerbit Raja Grafindo Persada,

Lubis, N. A., Siregar, D. C., \& Simanjuntak, F. (2018). Variasi Curah Hujan Diurnal di Aceh. Buletin BBMKG Wilayah II, 8(8), hh 14-20.

Masterson, J. M. \& Richardson, F. A. (1979). Humidex: A Method of Quantifying Human Discomfort due to Excessive Heat and Humidity, Environment Canada, Atmospheric Environment Service, Downsview, Ontario, CLI.

Rosianty, Y., Lensari, D., \& Handayani, P, (2018). Pengaruh Sebaran Vegetasi Terhadap Suhu dan Kelembaban Pada Taman Wisata Alam (TWA) Punti Kayu Kota Palembang. Jurnal Sylva, 7(2), 68-77.

Schoen, C. (2005). A New Emperical Model of the Temperature Humidity Index. American Meteorological Society, 44, 1413-1420. doi: 10.1175/JAM2285.1

Spridonov, V., Curic, M., \& Zafirovski, O, (2013). Weather and Human Health, Macedonian: COBISS M. K.

Thom, E. C. (1959). The Distribution Index. Weatherize. 12(2), 57-60.

Wati, T. \& Fatkhuroyan. (2017). Analisis Tingkat Kenyamanan di DKI Jakarta Berdasarkan Indeks THI (Temperature Humidity Index). Jurnal Ilmu Lingkungan. 15(1), 57-63. doi:10.14710/jil.15.1.5763 